\title{
Ny kunnskap om narkolepsi hos barn
}

\author{
I disse dager foreligger nye retningslinjer for behandling av barn med søvnsykdommen narkolepsi. De senere \\ årene har man fått økt kunnskap om årsaksmekanismer og kliniske uttrykksformer. Halvparten av pasien- \\ tene får sine første symptomer allerede i alderen 5-15 år, og symptomene kan være annerledes enn hos \\ voksne. Det er derfor viktig at også pediatere inkluderer narkolepsi i sitt kompetansefelt.
}

Mona Skard Heier

msheier@online.no

Michaela D. Gjerstad

Stine Knudsen

Narkolepsi er en kronisk sykdom med forstyrrelser i reguleringen av våkenhet, søvn og muskeltonus. Prevalensen i Norge er på ca. $0,22 \%$ (1). Sykdommen kan oppstå $\mathrm{i}$ alle aldre, men omtrent halvparten har fått sine første symptomer allerede før de fyller 15 år. En rekke studier fra inn- og utland har vist at det kan gå mange år fra de første symptomene viser seg til diagnosen blir stilt (2-4). Derfor har narkolepsi hovedsakelig vært et felt for nevrologer som diagnostiserer og behandler voksne.

Symptomene ved narkolepsi er først og fremst sterk søvnighet og ufrivillige søvnanfall, og ofte avbrutt søvn om natten. To tredeler av pasientene har også assosierte symptomer knyttet til REM-søvn. Mest karakteristisk er katapleksi, som er patognomonisk for narkolepsi og består av kortvarig tap av muskeltonus utløst av emosjonelle situasjoner, særlig latter. I tillegg kan det være hypnagoge hallusinasjoner (livaktige sanseopplevelser ved innsovning eller oppvåkning) og episoder med søvnparalyse (kortvarig muskellammelse ved oppvåkning). Disse to fenomenene kan imidlertid også forekomme ved andre søvnsykdommer og hos friske. Flere undersøkelser viser at sykdommen kan være svært invalidiserende (3-6). Ved spørreundersøkelser gir pasientene uttrykk for at tidligere diagnose og behandling ville ha medført bedret skolegang, yrkeskarriere og sosial tilpasning (3-6).

\section{Særtrekk ved narkolepsi hos barn}

De siste 10-15 år er man blitt mer oppmerksom på at sykdommen ofte debuterer tidligere enn man har vært klar over og at halvparten får sine første symptomer $i$ alderen 5-15 år (7-9). Flere nye studier er derfor rettet mot narkolepsi hos barn. De beskriver både symptomatologi og behandlingsmessige utfordringer som skiller seg fra det man finner hos voksne $(8,9)$.
Hypersomni med søvnanfall er, som ved narkolepsi hos voksne, oftest det første symptomet. Søvnepisodene på dagtid er imidlertid ofte mer langvarige, særlig hos de minste barna (6). Søvnanfall på skolen er problematisk, men også langvarige perioder med sterk søvnighet eller bare halvvåken tilstand gjør det umulig for barnet å få utbytte av undervisningen og huske beskjeder og informasjon. Enkelte barn misoppfattes også som «hyperaktive» i forsøket på å holde seg våkne.

Katapleksi kan være miskjent og mistolket, særlig hos de minste barna, der anfallene kan ha en annen utforming enn hos voksne. Selv om anfallene kan utløses ved latter eller andre følelser, er det ikke alltid noen klart anfallsutløsende situasjon. Anfallene starter ofte i ansiktsmuskulaturen, med dystonier og grimasering omkring kjeve og munn, eventuelt med protrusjon av tungen og snøvlende tale. Det kan også være mer generell tonusveksling med sjanglende og ataktisk preget gange, før anfallet eventuelt utvikles til mer typisk katapleksi med forbigående bilateral lammelse av muskulatur, eventuelt med fall (8). Slik atypisk, infantil katapleksi ser ut til å gå over til den mer vanlige «voksne» formen med alderen.

Hypnagoge hallusinasjoner kan være vanskelig å diagnostisere, dels fordi fenomenet oftest er ukjent både for barnet $\mathrm{og}$ foreldrene, dels fordi opplevelsene kan være ekstremt skremmende og groteske, så barnet nødig vil fortelle om dem. Plutselig oppstått redsel for å gå til sengs og ønske om å sove hos foreldrene kan være et uttrykk for dette. Nattesøvnen kan være preget av økt uro, ofte i form av parasomnier som søvngjengeri og ufullstendige oppvåkninger med forvirring (9). Det er hevdet at søvnparalyse ikke forekommer eller er sjelden hos barn, men dette er usikkert, siden barnet har vanskelig for å beskrive fenomenet og det ikke kan observeres utenfra.

Endokrine endringer, som vanligvis ikke ses ved narkolepsi hos voksne, kan være tilleggssymptomer hos barn. En markant og rask vektøkning på opptil $10-30 \mathrm{~kg}$ ses ofte, særlig i sykdommens startfase. Det er også beskrevet økt forekomst av for tidlig kjønnsmodning (pubertas praecox). Disse fenomenene kan tyde på en mer omfattende hypotalamisk affeksjon i en umoden hjerne (10).

Økt irritabilitet og uro, noen ganger med uttalt aggresjon, er ikke typisk ved narkolepsi hos voksne, men ses ofte hos barn. Noen ganger kan dette oppfattes som en måte å kompensere tretthet og søvnighet (overtretthet), men forandringen kan også være så uttalt at en slik forklaring ikke er rimelig. Depresjon og tilbaketrekning er vanlig og suicidaltanker kan forekomme (9).

\section{Hva vet vi om årsakene?}

I 1996 ble det søvn-, våkenhets- og tonusregulerende nevropeptidet hypokretin påvist i hypothalamus for første gang, og i 2000 ble det oppdaget at hypokretinmangel kan medføre narkolepsi (11-14). Siden har det skjedd en betydelig økning i forskningsbasert kunnskap om sykdommen. I dag skiller man mellom narkolepsi med hypokretinmangel og narkolepsi med normalt hypokretinnivå. Man har nå betydelig økt kunnskap om den første gruppen, mens patogenesen ved narkolepsi med normalt hypokretinnivå er mindre veldefinert.

Narkolepsi med katapleksi skyldes i ca. $90 \%$ av tilfellene et nesten totalt tap av hypokretinproduserende nevroner, med tilsvarende lavt hypokretininnhold i spinalvæsken (11-15). Mye tyder på at en autoimmun prosess utløser en destruksjon av hypokretinnevronene. Dette underbygges hovedsakelig av en sterk assosiasjon til vevstypeantigenet $H L A-D Q B 1 * 0602$ og en genetisk polymorfisme i T-cellereseptoralfa-genet, som begge finnes hos 95-98\% av alle narkolepsipasienter med hypokretinmangel (16). Man tenker seg at en autoimmun destruksjon av hypokretinnevronene aktiveres ved ytre påvirkninger hos genetisk predisponerte personer. Det har særlig vært interesse for enkelte infeksjoner som mulig utløsende faktorer. Streptokokkinfeksjoner er en mulig utløser, da man finner forhøyede titre av antistreptolysin hos et høyt antall pasienter med nyoppstått narkolepsi (17). Oppmerksomheten rettes nå særlig mot influensavirus etter at en kinesisk studie påviste svingninger i nye 


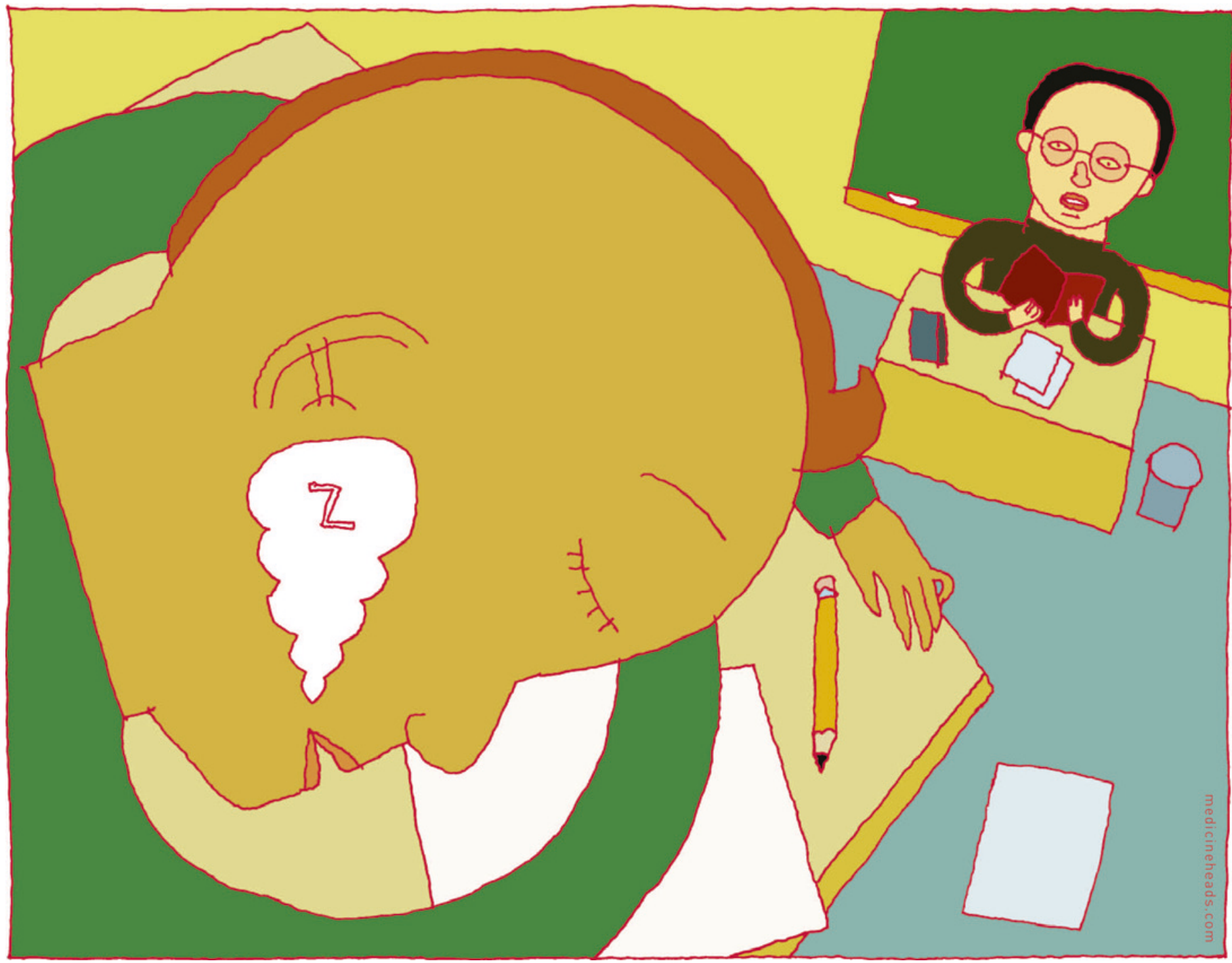

Illustrasjon () Trond Nordahl/medicineheads

tilfeller av narkolepsi hos barn, i takt med årlige influensaepidemier. Det var en topp under svineinfluensaen i 2009 (18). De fleste av disse barna var ikke vaksinerte.

H1N1-influensavaksineringen 2009 Ifølge europeiske studier er narkolepsiinsidensen $i$ aldersgruppen 5-20 år vanligvis ca. $0,5-1 / 100000$. Forventet årlig insidens i Norge er da 5-10 nye tilfeller i denne aldersgruppen (19). I november og desember 2009 ble det foretatt massevaksinering med vaksinen Pandemrix mot svineinfluensaviruset H1N1. Vaksinasjonsdekningen i aldersgruppen 5-20 år var $50 \%$, ca. 450000 vaksinerte og 450000 uvaksinerte barn. De første to årene etter vaksineringen fikk 58 vaksinerte barn symptomer på narkolepsi (20). $42 \mathrm{av}$ dem fikk symptomer allerede innen seks måneder. Antallet tilsvarte en narkolepsi- insidens blant vaksinerte barn på mer enn 10/100 000/år i 2010 - en tidobling av forventet insidens. I samme periode fikk fem uvaksinerte barn verifisert narkolepsi, i overensstemmelse med normal insidens. Sammenhengen mellom vaksineringen og den kraftige økningen i tilfeller av narkolepsi fant man også $\mathrm{i}$ andre land som hadde benyttet Pandemrix-varianten av influensavaksine (Finland, Sverige, Irland, England, Frankrike).

Felles for de undersøkte barna var at de hadde vevstypeantigenet $H L A D Q B 1 * 0602$, sterkt nedsatt hypokretininnhold i spinalvæsken og en påfallende fulminant sykdomsdebut. Symptomene oppsto brått med sterk hypersomni hos alle. Katapleksi og de øvrige symptomene oppsto omtrent samtidig og var uvanlig uttalte. Særlig de minste barna hadde katapleksi med den beskrevne infantile utformingen. Av 58 hadde 22 en vektøkning på 5-30 kg de første seks månedene. Påfallende aggresjon og irritabilitet ble beskrevet hos seks av barna. Flere av foreldrene fortalte at barna sov urolig, var blitt redde for å legge seg eller ville sove i foreldrenes seng, og enkelte av de større barna beskrev hypnagoge hallusinasjoner. Det kliniske bildet passer derfor med de observasjonene som tidligere er gjort av infantil narkolepsi, men $i$ en uvanlig fulminant form. Man tenker seg at komponenter i vaksinen har utløst en kraftig immunrespons og rask ødeleggelse av de hypokretinproduserende nevronene i hypothalamus. Muligens har de også affisert andre sentralnervøse strukturer hos genetisk predisponerte barn (20).

\section{Flere behandlingsalternativer}

Økt kunnskap om årsaksmekanismer og kliniske uttrykksformer har gitt bedre mulig- 
heter for tidlig diagnose og behandlingsstart. I tillegg til medikamentell behandling vil det oftest være behov for individuell tilpasning av livsstil og søvnvaner samt pedagogisk tilrettelegging i samarbeid mellom hjem, barnehage og skole (21). Medikamentell behandling er i hovedsak symptomatisk og primært siktet inn på å redusere søvnighet, søvnanfall og de mest plagsomme tilleggssymptomene. Et økt tilfang av medikamenter gjør at man i dag bedre kan tilpasse behandlingen individuelt. De norske refusjonsbestemmelsene er imidlertid ikke oppdaterte og kan begrense behandlingsmulighetene, siden det bare gis refusjon for amfetamin, som ikke anbefales til barn, og for metylfenidat i tablettform med korttidseffekt. De vanligst benyttede medikamentene mot hypersomni ved narkolepsi hos barn er fortsatt sentralstimulerende midler som metylfenidat, som nå foreligger i formuleringer med varierende virketid, i tillegg til det nyere midlet modafinil, som har mindre omfattende effekt på sentralnervesystemet. Mot katapleksi, hypnagoge hallusinasjoner og søvnparalyse benyttes serotonin- og/eller adrenalinreopptakshemmere. I tillegg har natriumoksybat vist seg å ha meget god effekt mot de fleste symptomene ved narkolepsi (9). Foreløpig er man tilbakeholden med å gi dette til barn, siden det krever nøye tilpasset dosering, svært langsom doseopptrapping og nøyaktig etterlevelse.

\section{Konklusjon}

Omtrent halvparten av pasientene med narkolepsi får sine første symptomer i alderen 5-15 år. Ny kunnskap om symptomatologien hos barn bør øke muligheten for tidligere diagnose og behandling. Etter massevaksineringen med Pandemrix i 2009 har vi fått en ny situasjon i Norge, med et betydelig økt antall barn med fulminant narkolepsi. Disse og andre barn med narkolepsi vil ha behov for kompetent medisinsk og psykososial oppfølging og behandling i mange år fremover. Nasjonalt kompetansesenter for $\mathrm{AD} / \mathrm{HD}$, Tourettes syndrom og narkolepsi har derfor, i samarbeid med Helsedirektoratet, utarbeidet en veileder for behandling av barn med narkolepsi (21).

\section{Mona Skard Heier (f. 1939)}

er spesialist i nevrologi og klinisk nevrofysiologi. Hun er tidligere seksjonsoverlege ved Klinisk nevrofysiologisk laboratorium, Ullevål universitetssykehus, nå konsulent ved Nasjonalt kompetansesenter for AD/HD, Tourettes syndrom og narkolepsi.

Forfatter har fylt ut ICMJE-skjemaet og oppgir ingen interessekonflikter.

\section{Michaela D. Gjerstad (f. 1970)}

er spesialist i nevrologi, overlege ved Nevrologisk avdeling, Stavanger universitetssjukehus, konsulent ved Nasjonalt kompetansesenter for AD/HD, Tourettes syndrom og narkolepsi og ved Nasjonal kompetansetjeneste for søvnsykdommer, Bergen.

Forfatter har fylt ut ICMJE-skjemaet og oppgir ingen interessekonflikter.

\section{Stine Knudsen (f. 1969)}

er spesialist i nevrologi, overlege i deltidsstilling ved Nasjonalt kompetansesenter for AD/HD, Tourettes syndrom og narkolepsi og avdelingslege ved Dansk Center for Søvnmedicin, Klinisk neurofysiologisk afdeling, Glostrup Hospital, Københavns Universitet.

Forfatter har fylt ut ICMJE-skjemaet og oppgir ingen interessekonflikter.

\section{Litteratur}

1. Heier MS, Evsiukova T, Wilson J et al. Prevalence of narcolepsy with cataplexy in Norway. Acta Neurol Scand 2009: 120: 276-80.

2. Morrish E, King MA, Smith IE et al. Factors associated with a delay in the diagnosis of narcolepsy. Sleep Med 2004; 5: 37-41.

3. Jennum P, Ibsen R, Petersen ER et al. Health social, and economic consequences of narcolepsy: a controlled national study evaluating the societal effect on patients and their partners. Sleep Med 2012; 13: 1086-93.

4. Ingravallo F, Gnucci V. Pizza F et al. The burden of narcolepsy with cataplexy: how disease history and clinical features influence socio-economic outcomes. Sleep Med 2012; 13: 1293-300.

5. Dauvilliers Y, Arnulf I, Mignot E. Narcolepsy with cataplexy. Lancet 2007; 369: 499-511.

6. Ervik S, Abdelnoor M, Heier MS et al. Health-related quality of life in narcolepsy. Acta Neurol Scand 2006; 114: 198-204.

7. Heier MS. Narkolepsi hos barn - en diagnostisk og terapeutisk utfordring. Tidsskr Nor Lægeforen 1998; 118: 2691-3.

8. Aran A, Einen M, Lin L et al. Clinical and therapeutic aspects of childhood narcolepsy-cataplexy: a retrospective study of 51 children. Sleep 2010; 33: $1457-64$

9. Nevsimalova S. Narcolepsy in childhood. Sleep Med Rev 2009; 13: 169-80.

10. Poli F, Pizza F, Mignot E et al. High prevalence of precocious puberty and obesity in childhood narcolepsy with cataplexy. Sleep 2013; 36: 175-81.

11. Gautvik KM, de Lecea L, Gautvik VT et al. Overview of the most prevalent hypothalamus-specific mRNAs, as identified by directional tag PCR subtraction. Proc Natl Acad Sci U S A 1996; 93: 8733-8.

12. Thannickal TC, Moore RY, Nienhuis R et al. Reduced number of hypocretin neurons in human narcolepsy. Neuron 2000; 27: 469-74.

13. Knudsen S, Jennum PJ, Alving J et al. Validation of the ICSD-2 criteria for CSF hypocretin-1 measurements in the diagnosis of narcolepsy in the Danish population. Sleep 2010; 33: 169-76.

14. Mignot E, Lammers GJ, Ripley B et al. The role of cerebrospinal fluid hypocretin measurement in the diagnosis of narcolepsy and other hypersomnias. Arch Neurol 2002; 59: 1553-62.

15. Heier MS, Evsiukova T, Vilming $S$ et al. CSF hypocretin-1 levels and clinical profiles in narcolepsy and idiopathic CNS hypersomnia in Norway. Sleep 2007; 30: 969-73.

16. Mignot E, Hayduk R, Black J et al. HLA DQB $1 * 0602$ is associated with cataplexy in 509 narcoleptic patients. Sleep 1997: 20: 1012-20.

17. Aran A, Lin L, Nevsimalova S et al. Elevated antistreptococcal antibodies in patients with recent narcolepsy onset. Sleep 2009; 32: 979-83.

18. Han F, Lin L, Warby SC et al. Narcolepsy onset is seasonal and increased following the $2009 \mathrm{H} 1 \mathrm{~N} 1$ pandemic in China. Ann Neurol 2011; 70: 410-7.

19. Wijnans L, Lecomte C, de Vries C et al. The incidence of narcolepsy in Europe: before, during, and after the influenza A(H1N1)pdm09 pandemic and vaccination campaigns. Vaccine 2013; 31 $1246-54$

20. Heier MS, Gautvik KM, Wannag E et al. Narcolepsy in Norwegian children and adolescents after vaccination against $\mathrm{H} 1 \mathrm{~N} 1$ influenza $\mathrm{A}$. Sleep Med 2013; doi:10.1016/j,sleep.2013.03.020.

21. Retningslinjer for utredning og behandling av barn og ungdom med narkolepsi. Oslo: Nasjonalt kompetansesenter for AD/HD, Tourettes syndrom og narkolepsi, 2013. www.nasjkomp.no og www. helsedirektoratet.no (30.4.2013).

Mottatt 20.3. 2013, første revisjon innsendt 17.4 2013, godkjent 30.4. 2013. Medisinsk redaktør Hanne Støre Valeur.

Podkast på www.tidsskriftet.no

Publisert først på nett. 